\title{
Prediction of Species Richness of Breeding Birds by Analysis of Land Cover at Seongnam City, Korea
}

\author{
Park, Chan-Ryul*, Jangho Lee, Dowon Lee ${ }^{1}$ and Woo-Shin Lee ${ }^{2}$ \\ *University Forests, Seoul National University, Seoul 151-742, Korea \\ ${ }^{\prime}$ Graduate School of Environmental Studies, Seoul National University, Seoul 15I-742, Korea \\ ${ }^{2}$ Department of Forest Sciences, Seoul National University, Seoul 151-742, Korea
}

\begin{abstract}
This study was conducted to develop the predictive model for species richness of breeding birds by multivariate analysis of land covers (percentage value of each cover in $300 \times 300 \mathrm{~m}$ grid) including water area (WA), urbanized area (UA), green area (GA), forest area (FA) and agricultural area (AA) at Seongnam City in Korea. Fifty-nine species of birds were mapped on 155 grids in size of $300 \times 300 \mathrm{~m}$ from 2000 to 2001. Species richness of breeding birds was significantly regressed $\left(R^{2}=0.85, n=155\right)$ by estimates of WA $(4.59 \pm 1.13$,

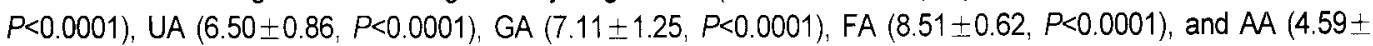
$1.13, P<0.0001)$. In validation of model, the results show no significant difference between predicted value of species richness and observed one. Developed model can be used as a predictive model of species richness of birds for selecting the proper location of corridors and parks in urban area.
\end{abstract}

Key words: Breeding birds, Forest-dominated landscape, Land cover, Species richness

\section{INTRODUCTION}

It has been recognized that birds respond to landscape patterns at coarser spatial scales (Freemark and Merriam 1986, Freemark et al. 1995, Edwards et al. 1996, Howell et al. 2000). Many researchers have tried to predict the probability of presence of specific birds by habitat suitability index (HSI, US Fish and Wildlife Service 1981), gap analysis project (GAP, Scott et al. 1993), and predictive habitat models for specific birds (Verner et al. 1986, Dettmers and Bart 1999, Saveraid et al. 2001, Lawler and Edwards 2002). Previous models and methodology can be applied to the conservation of specific species, however, models that predict the overall species richness of breeding birds will be better at selecting effective parks for enhancing the species richness of birds in urban area (Vuilleumier and Prelaz-Droux 2002). Although regression technique would be easy to build model interpretative (De' ath and Fabricius 2000), there has hardly been any simple regression model based on associations with landscape patterns (Lawler and Edwards 2002). Ecological networks for landscape planning are need to maintain and increase biodiversity in urban fragmented landscape (Vuilleumier and Prelaz-Droux 2002), and landscape composition of specific area can play an important role in networking and enhancing the movement of birds in urban area. Therefore this study was conducted to develop the predictive model of species richness of breeding birds by analysis of land cover derived from Landsat TM imagery.

\section{MATERIALS AND METHODS}

\section{Study area and site selection}

This study was conducted at Seongnam City (East: 127 $11^{\prime} 22^{\prime \prime}$, West: $127^{\circ} 1^{\prime} 17^{\prime \prime}$, South: $37^{\circ} 19^{\prime} 54^{\prime \prime}$, North: $37^{\circ} 23^{\prime} 23^{\prime \prime}$ ), where located at a distance of $26 \mathrm{~km}$ to the South of Seoul City, capital of Korea. Seongnam City has a population of 930,000 and a total area of 142 square kilometer, where the old town area (Sujeong-gu and Jungwon-gu) coexists with the new town area (Bundang-gu, developed in the 90s). In Seongnam City, ten rivers and five reservoirs are connected to Tanchon River that runs through the middle part of the City and flows down to Han River. Pattern of land use shows that forests dominate $50.8 \%$ of the geographical area of the city whereas residential areas and roads occupy $12.4 \%, 7.9 \%$ of the area respectively. Annual mean temperature was $12.3^{\circ} \mathrm{C}$ and precipitation was $1,328.8 \mathrm{~mm}$ in 2000 (Seongnam City 2001). Subsequent to setting 1,564 grids in size of $300 \times 300 \mathrm{~m}$, we surveyed breeding birds at six groups of 155 grids selected by the procedure of average neighbor method of cluster analysis of land cover with SAS statistical package (SAS Institute Inc. 1985, Fig. 1). After cluster analysis we selected additional 15 grids from each clustered group for validation of developed model.

\footnotetext{
* Corresponding author; Division of Forest Ecology, Korea Forest Research Institute, e-mail: park@foa.go.kr, chandrap@chol.com
} 


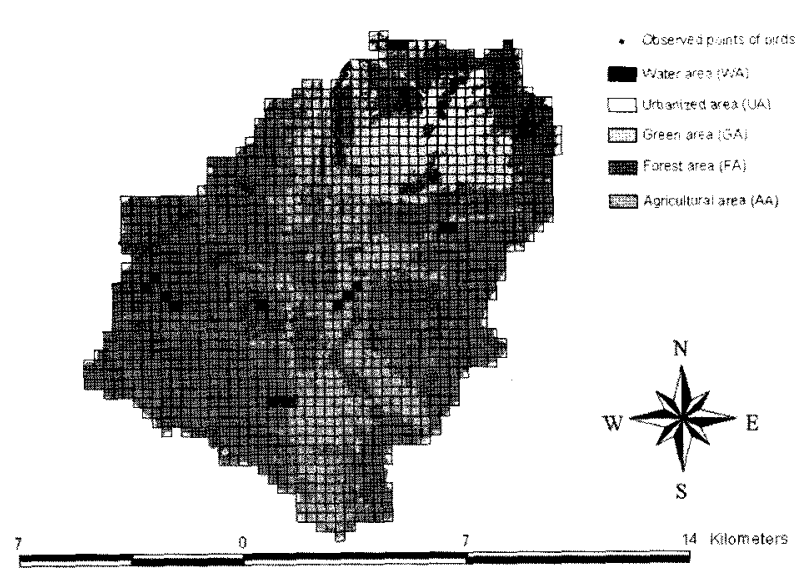

Fig. 1. Analyzed pattern of land cover at each $30 \times 30 \mathrm{~m}$ cell and observed points of birds in Seongnam City, Korea (Grids show survey units for bird community in size of $300 \times 300 \mathrm{~m}$, shaded grids show the validation grids).

\section{Birds' survey and analysis of land cover}

Survey of breeding birds was carried out in April, May and June of 2000 and 2001, respectively. To avoid bias from repeated observations of the same individuals, we surveyed birds with walking at the speed of $2 \mathrm{~km}$ per hour between 0700 and 1200 in clear day. Birds were identified by binoculars $(8 \times 30)$, song and call, and number of individuals were counted and recorded (Bibby et al. 1997). We visit each survey grid no more than two times in one year. During the survey period, two years, the minimum number of individuals of breeding birds was mapped on each grid in the 1:5000 scale digital topographic maps published by National Geographic Information Institute, Korea. Observed points were mapped on the digital map with ArcInfo Ver. 8.0 and ArcView Ver. 3.2 software (ESRI 1999). Landsat TM color composite of May in 1998, with $30 \mathrm{~m}$ spatial resolution was classified by ERDAS IMAGINE 8.4 software (Anon 1995). A supervised classification of May in 1998 Landsat Thematic Mapper (TM) imagery performed by using field survey data creates five general land-cover types, including water area (WA), urbanized area (UA), green area (GA), forest area (FA), and agricultural area (AA). After classification of land cover, we calculated the percentage value of each cover at each grid in size of $300 \times 300 \mathrm{~m}$ with the application of ArcInfo 8.0 and ArcView 3.2 software (ESRI 1999). Also, we calculated the number of species and number of individuals at each grid.

\section{Multiple regressive model and validation procedure}

The multiple regressive model was established by variables of land cover. We conducted the arcsine transformation of each ratio of land cover for statistical analysis of variables. Testing the validity of this model was conducted by comparing predicted values with the observed values of number of species and individuals with Kruskal-Wallis test $(P<0.05)$.

\section{RESULTS}

\section{Classification of land cover}

In the supervised classification, land cover of study area was classified into several classes. Water area (WA) ranged from 0.0 to 77.8 percent. It averaged 0.4 percent per one grid cell and was occurred in 134 grids. Urbanized area (UA) ranged from 0.0 to 100.0 percent. It averaged 13.8 percent per one grid cell and was observed in 897 grids. Green area (GA) ranged from 0.0 to 80.0 percent. It averaged 9.0 percent per one grid cell and was distributed in 1,106 grids. Forest area (FA) ranged from 0.0 to 100.0 percent. It averaged 55.8 percent per one grid cell and was found in 1,417 grids. Agricultural area (AA) ranged from 0.0 to 97.0 percent. It averaged 16.5 percent per one grid cell and was present in 1,163 grids. As a result, landscape pattern of Seongnam city was dominated by FA $(7,856.8$ ha, 55.8\%), UA $(2,581.8$ ha, 18.3\%), AA $(2,326.7$ ha, 16.5\%), GA $(1,271.4$ ha, 9.0\%) and WA (50.9 ha, $0.4 \%$ ) in order (Fig. 1).

\section{Dominance and distribution of recorded birds}

During the observation period fifty-nine species of birds were observed in study area. Tree sparrow Passer montanus dominated this area as 298 individuals (19.3\%), black-billed magpie Pica pica did as 192 individuals (12.4\%), vinous-throated parrotbill Paradoxornis webbiana was 178 individuals (11.5\%), domestic dove Columba livia was 107 individuals (6.9\%) and great tit Parus major was 91 individuals $(5.9 \%)$ in order. Black-billed magpie was the species having the most extensive distribution. It was recorded in 48 grids (31.0\%). Other than black-billed magpie, great tit was present in 42 grids (27.1\%), marsh tit Parus palustris was distributed over 39 grids $(25.2 \%)$, tree sparrow was observed in 31 grids $(20.0 \%)$, little egret Egretta garzetta was found in 27 grids $(17.4 \%)$, vinousthroated parrotbill was distributed in 23 grids $(14.8 \%)$, and rufous turtle dove Streptopelia orientalis was present in 21 grids (13.5\%). The rest of species, such as Cettia diphone, Sturnus cineraceus, Luscinia sibilans, Cettia squmaeiceps, Tringa ochropus, Cuculus fugax, Cuculus poliocephalus and Phylloscopus tenelipes, were observed only in one grid (Table 1).

On one side, in 155 grids, the number of species per one grid cell ranged from one to thirteen species. Fifty grids, one third of all grids, had only one species and 78 grids had over two and below five species. On the other hand over six and below ten species were observed in 25 grids and over ten species were found in two grids 
Table 1. Number of individuals and occupied grids of observed birds in selected 155 grids

\begin{tabular}{|c|c|c|c|c|c|c|c|c|c|}
\hline \multirow{2}{*}{$\frac{\text { Scientific name }}{\text { Passer montanus }}$} & \multicolumn{2}{|c|}{ N.I. $(\%)^{l}$} & \multicolumn{2}{|c|}{ N.O. $(\%)^{2}$} & \multirow{2}{*}{$\begin{array}{l}\text { Scientific name } \\
\text { Otus scops }\end{array}$} & \multicolumn{2}{|c|}{ N.I. $(\%)^{1}$} & \multicolumn{2}{|c|}{ N.O. $(\%)^{2}$} \\
\hline & 298 & (19.3) & 31 & $(20.0)$ & & 7 & $(0.5)$ & 6 & $(3.9)$ \\
\hline Pica pica & 192 & $(12.4)$ & 48 & $(31.0)$ & Phoenicurus auroreus & 7 & $(0.5)$ & 5 & $(3.2)$ \\
\hline Paradoxornis webbiana & 178 & $(11.5)$ & 23 & $(14.8)$ & Acrocephalus orientalis & 7 & $(0.5)$ & 1 & $(0.6)$ \\
\hline Columba livia & 107 & $(6.9)$ & 16 & $(10.3)$ & Picus canus & 6 & $(0.4)$ & 5 & $(3.2)$ \\
\hline Parus major & 91 & $(5.9)$ & 42 & $(27.1)$ & Turdus naumanni naumanni & 6 & $(0.4)$ & 2 & (1.3) \\
\hline Parus palustris & 82 & $(5.3)$ & 39 & $(25.2)$ & Phylloscopus coronatus & 5 & $(0.3)$ & 2 & $(1.3)$ \\
\hline Ardea cinerea & 58 & $(3.7)$ & 17 & $(11.0)$ & Accipiter soloensis & 5 & $(0.3)$ & 5 & $(3,2)$ \\
\hline Hirundo rustica & 57 & $(3.7)$ & 16 & $(10.3)$ & Lanius bucephalus & 5 & $(0.3)$ & 4 & $(2.6)$ \\
\hline Egretta garzetta & 48 & $(3.1)$ & 27 & $(17.4)$ & Caprimulgus indicus & 4 & $(0.3)$ & 4 & $(2.6)$ \\
\hline Egretta alba & 42 & $(2.7)$ & 20 & $(12.9)$ & Phylloscopus borealis & 4 & $(0.3)$ & 2 & (1.3) \\
\hline Streptopelia orientalis & 31 & $(2.0)$ & 21 & $(13.5)$ & Upupa epops & 3 & $(0.2)$ & 2 & $(1.3)$ \\
\hline Oriolous chinensis & 25 & $(1.6)$ & 13 & ( 8.4) & Falco tinnunculus & 3 & $(0.2)$ & 3 & (1.9) \\
\hline Anas poecilorhyncha & 21 & $(1.4)$ & 3 & $(1.9)$ & Dendrocopos leucotos & 3 & $(0.2)$ & 3 & (1.9) \\
\hline Dendrocopos major & 21 & ( 1.4) & 19 & $(12.3)$ & Hirundo daurica & 3 & $(0.2)$ & 2 & $(1.3)$ \\
\hline Dendrocopos kizuki & 21 & $(1.4)$ & 15 & $(9.7)$ & Cyanoptila cyanomelana & 2 & $(0.1)$ & 2 & $(1.3)$ \\
\hline Motacilla alba & 17 & $(1.1)$ & 11 & $(7.1)$ & Phylloscopus tenellipes & 2 & $(0.1)$ & 1 & $(0.6)$ \\
\hline Hypsipetes amaurotis & 16 & $(1.0)$ & 8 & $(5.2)$ & Cuculus saturatus & 2 & $(0.1)$ & 2 & $(1.3)$ \\
\hline Parus varius & 16 & $(1.0)$ & 7 & $(4.5)$ & Bonasa bonasia & 2 & $(0.1)$ & 2 & $(1.3)$ \\
\hline Nycticorax nycticorax & 15 & $(1.0)$ & 7 & $(4.5)$ & Charadrius dubius & 2 & $(0.1)$ & 1 & $(0.6)$ \\
\hline Parus ater & 15 & $(1.0)$ & 9 & $(5.8)$ & Actitis hypoleucos & 2 & $(0.1)$ & 1 & $(0.6)$ \\
\hline Phasianus colchicus & 14 & $(0.9)$ & 11 & $(7.1)$ & Cuculus micropterus & 2 & $(0.1)$ & 2 & $(1.3)$ \\
\hline Aegithalos caudatus & 13 & $(0.8)$ & 5 & $(3.2)$ & Cettia diphone & 1 & $(0.1)$ & 1 & $(0.6)$ \\
\hline Garrulus glandarius & 13 & $(0.8)$ & 9 & $(5.8)$ & Sturnus cineraceus & 1 & $(0.1)$ & 1 & $(0.6)$ \\
\hline Motacilla cinerea & 12 & $(0.8)$ & 7 & $(4.5)$ & Luscinia sibilans & 1 & $(0.1)$ & 1 & $(0.6)$ \\
\hline Eurystomus orientalis & 11 & $(0.7)$ & 7 & $(4.5)$ & Cettia squameiceps & 1 & $(0.1)$ & 1 & $(0.6)$ \\
\hline Butorides striatus & 11 & $(0.7)$ & 8 & $(5.2)$ & Tringa ochropus & 1 & $(0.1)$ & 1 & $(0.6)$ \\
\hline Turdus pallidus & 9 & $(0.6)$ & 3 & $(1.9)$ & Cuculus fugax & 1 & $(0.1)$ & 1 & $(0.6)$ \\
\hline Emberiza elegans & 9 & $(0.6)$ & 6 & $(3.9)$ & Cuculus poliocephalus & 1 & $(0.1)$ & 1 & $(0.6)$ \\
\hline Cuculus canorus & 8 & $(0.5)$ & 8 & $(5.2)$ & Phylloscopus tenelipes & 1 & $(0.1)$ & 1 & $(0.6)$ \\
\hline Zoothera dauma & 7 & $(0.5)$ & 7 & $(4.5)$ & Number of species & 59 & & & \\
\hline
\end{tabular}

: Number of individuals, ${ }^{2}:$ number of observed grids.

consequently.

The number of individuals per one grid ranged from 1 to 52 individuals. Grids occupied by only one individual were 19 , by over two and below five individuals were 60 grids, by over six and below ten individuals were 31 , by over eleven and below twenty individuals were 29 , by over 21 individuals and below 50 individuals were 14 and finally by over 51 individuals were only 2 (Table 1 ).

\section{Regressive models and their validities}

In multiple regression analysis, the number of species was signi- 
ficantly $\left(\mathrm{F}_{5}, 149=169.19, P<0.0001, R^{2}=0.85, \mathrm{n}=155\right)$ regressed by intercept $(-6.16 \pm 0.88, P<0.0001)$ and estimates of water area (WA; $4.59 \pm 1.13, P<0.0001$ ), urbanized area (UA; 6.50 $\pm 0.86, P<0.0001$ ), green area (GA; 7.11 $\pm 1.25, P<0.0001)$, forest area (FA; $8.51 \pm 0.62$, $P<0.0001$ ), and agricultural area (AA; $4.59 \pm 1.13, P<0.0001$ ). Whereas, the number of individuals was significantly $\left(\mathrm{F}_{5},{ }_{149}=28.43, P<\right.$ $\left.0.0001, R^{2}=0.49, \mathrm{n}=155\right)$ regressed by intercept $(-23.36 \pm 6.81, P<$ $0.001)$ and estimates of urbanized area (UA; $24.99 \pm 6.65, P<0.001)$, green area $(\mathrm{GA} ; 25.04 \pm 9.66, P<0.05)$, forest area $(\mathrm{FA} ; 28.97 \pm 4.84$, $P<0.0001$ ), and agricultural area (AA; 25.21 $\pm 8.17, P<0.001)$ except the estimate of water area (WA; $17.17 \pm 8.75, P=0.0516$ ) (Table 2, Fig. 2, Fig. 3). The results of validation test show no significant difference between predicted value of species richness and observed (Kruskal-Wallis test; $\chi^{2}: 3.13, P<0.0769$ ). Accordingly, the way of estimation of species distribution might be well applied to another area. In this study predicted values of species richness in old town area (Sujeong-gu and Jungwon-gu) were significant higher ( $t$-value:

Table 2. Estimated parameter and standard error of dependents by multiple regression analysis $(\mathrm{n}=155)$

\begin{tabular}{lcc}
\hline \multirow{2}{*}{ Variables } & \multicolumn{2}{c}{ Dependents } \\
\cline { 2 - 3 } Intercept & $-6.16 \pm 0.88^{* * *}$ & $-23.36 \pm 6.81^{* *}$ \\
River and wetland & $4.59 \pm 1.13^{* * *}$ & $17.17 \pm 8.75$ \\
Urban area & $6.50 \pm 0.86^{* * *}$ & $24.99 \pm 6.65^{* *}$ \\
Green area & $7.11 \pm 1.25^{* * *}$ & $25.04 \pm 9.66^{*}$ \\
Forest & $8.51 \pm 0.62^{* * *}$ & $28.97 \pm 4.84^{* * *}$ \\
Agricultural land & $7.25 \pm 1.05^{* * *}$ & $25.21 \pm 8.17^{* *}$ \\
F value & $\mathrm{F}_{5,} 149^{*}=169.19^{* * *}$ & $\mathrm{~F}_{5,149}=28.43^{* * *}$ \\
$\mathrm{R}^{2}$ & 0.85 & 0.49 \\
\hline
\end{tabular}

${ }^{*} p<0.05,{ }^{* *} p<0.001,{ }^{* * *} p<0.0001$.

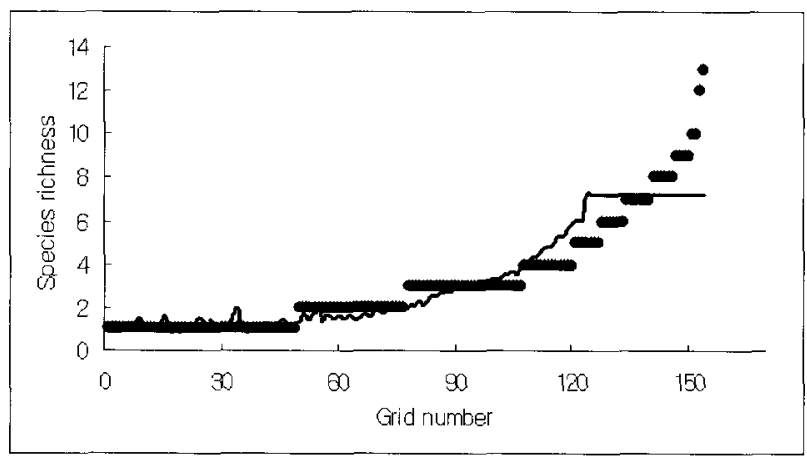

Fig. 2. Comparison of observed value (closed circle) and predicted value (solid line) of species richness in each grid (Grids are arranged in order of number of species).

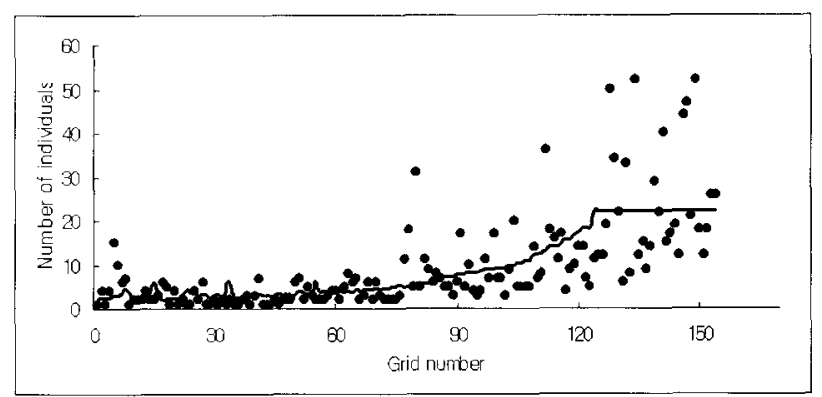

Fig. 3. Comparison of observed value (closed circle) and estimated value (solid line) of number of individuals in each (Grids are arranged in order of number of individuals).

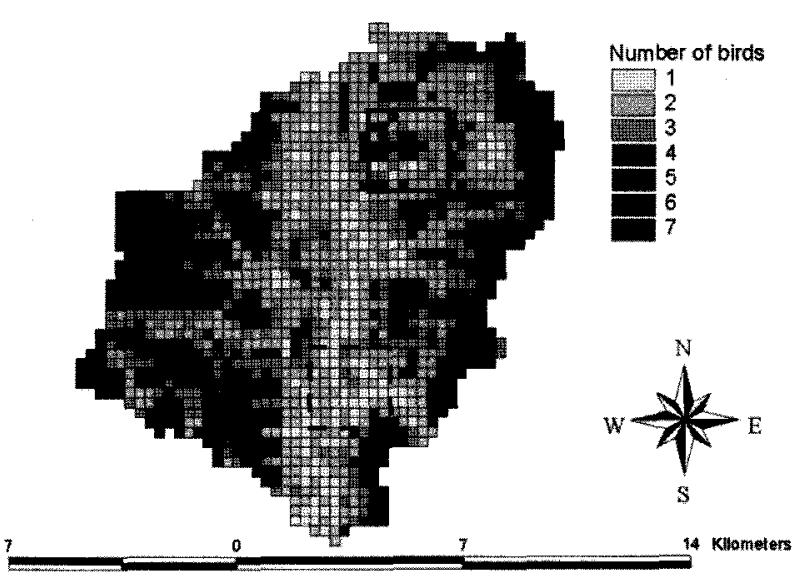

Fig. 4. Distribution of predicted values of species richness of birds and comparison of predicted values ( $t$-value: $6.54, P<.0001$, old town area $(\mathrm{n}=64) ; 1.97 \pm 1.25$, new town area $(\mathrm{n}=64) ; 0.75 \pm$ 0.81 ) between old town area (solid line square) and new town area (dashed line square) in Seongnam City, Korea.

6.54, $\mathrm{P}<.0001$, old town area $(\mathrm{n}=64) ; 1.97 \pm 1.25$, new town area $(\mathrm{n}=64) ; 0.75 \pm 0.81$ ) than the one in new town area (Bundang-gu) developed in the 1990s, although new town area has large park (Fig. 1, Fig. 4).

\section{DISCUSSION}

Avian researchers have revealed that bird species diversity would be determined by most micro-habitat features, such as vertical vegetation layers, the foliage structure and the snag density, which cannot be interpreted with remotely sensed data at the landscape level. In addition specific species and a couple of guild were shown to have good habitat relations with microhabitat features (Milsom et al. 2000, Saveraid et al. 2001, Lawler and Edwards 2002). On the other hand urban planner requires the easy, accurate and general model predicting the overall species richness of birds as conservation and management tools (Van Horne and Wiens 1991). Species 
richness of birds was easily predicted by landscape cover in this area even though it was modeled as seven species within 9 ha grid which were just dominated by forest area (Fig. 2). It means this model can be not so good to compare and discern species richness among grids fully covered by forest area. Furthermore we could not consider the vertical structure (Flather et al. 1992), tree species composition (Holmes and Schultz 1986, Whelan 2001), and vegetation characteristics (Howell et al. 2000), which might significantly affect the species richness of birds in forest-dominated grids. However, this model can be useful for predicting species richness of birds in urbanized area. This model can be utilized by urban planner who wants to select the effective corridor for enhancing the species richness of birds in urbanized area. So, it is need to consider the forestrelated environmental factors (e.g. vertical structure, tree species composition and dbh distribution) for practical application of model in urbanized and forest-dominated grids. According to this predicted value of species richness the old town area had the higher value of species richness of birds even though the forests of the old town was isolated, not well connected with each other. It might be related with the fact that new park and green area in new town area would not proper enough for birds to breed. In Tucson metropolitan area, species richness of birds was correlated strongly with not only artificial land cover (i.e., housing density and percentage paved) but also natural land cover (i.e., upland Sonoran cover and undisturbed riparian) within the Sonoran Desert landscape (Germaine et al. 1998). However, this study area was surrounded by forest-dominated landscape (Seongnam City 2001), also forest size of this study area was a good estimator of the number of breeding birds in Seoul City located near this area (Park and Lee 2000). Therefore species richness of birds was highly regressed by the land cover in this study. This model could not be sensitive to the specific species even if we recorded birds related with wetlands and river, such as spot-billed duck Anas poecilorhyncha and oriental great reed warbler Acrocephalus orientalis, which can breed at small area of riparian vegetation area in river area. The remotely sensed imagery was not suitable for fine scale information about birds in specific sites or areas (Saveraid et al. 2001), but each species have a tendency to respond to their habitat at different spatial scales (Wiens 1989). Therefore this model may not be applicable to predict the presence of specific species of birds at specific spatial scale. Nevertheless, this study suggests that species richness of birds may be well predicted by landscape pattern where is consisted of a couple of elements.

\section{ACKNOWLEDGEMENT}

This study was supported by a grant from Seongnam City, awarded to Environmental Planning Institute of Seoul National University. Thanks to Mr. EngKyoung Lee and Ms. KyungA Kim at Environmental \& Human Systems Research Institute of E-Jang Co., LTD. for valuable comments and discussion in GIS and RS data. We are also grateful to Ms. Jeehye Park for her revision on our early draft manuscript. This study was partially supported by the Post-doctoral Fellowship Program of Korea Science and Engineering Foundation (KOSEF).

\section{LITERATURE CITED}

Anon, Z. 1995. ERDAS IMAGINE, 8.4 field guide edition. ERDAS Ine., Atlanta, GA.

Bibby, C.J., N.D. Burgess and D.A. Hill. 1997. Bird census technique. Academic press limited. London, UK. 257p.

De' ath, G. and K.E. Fabricius. 2000. Classification and regression trees: a powerful yet simple technique for ecological data analysis. Ecology 81: 3178-3192

Dettmers, R. and J. Bart. 1999. A GIS modeling method applied to predicting forest songbird habitat. Ecol. Appl. 9: 152-163.

Edwards, T.C.Jr., E.T. Deshler, D. Foster and G.G. Moisen. 1996. Adequacy of wildlife habitat relation models for estimating spatial distributions of terrestrial vertebrates. Conserv. Biol. 10: 263-270.

ESRI. 1999. ArcInfo 8.0 and ArcView 3.2. Environmental Systems Research Instituted Inc., Redlands, CA.

Flather, C.H., S.J. Brady and D.B. Inkley. 1992. Regional habitat appraisals of wildlife communities: a landscape-level evaluation of a resource planning model using avian distribution data. Landscape Ecol. 7: 137-147.

Freemark, K.E. and H.G. Merriam. 1986. Importance of area and habitat heterogeneity to bird assemblages in temperate forest fragments. Biol. Conserv. 36: 115-141.

Freemark, K.E., J.B. Dunning, S.J. Hejl and J.R. Probst. 1995. A landscape ecology perspective for research, conservation, and management. In T.E. Martin and D.M. Finch (eds.), Ecology and management of neotropical migrant birds. Oxford University Press, New York, USA. pp. 381-421.

Germaine, S.S., S.S. Rosenstock, R.E. Schweinsburg and W.S. Richardson. 1998. Relationship among breeding birds, habitat, and residential development in greater Tucson, Arizona. Ecol. Appl. 8: 680-691.

Holmes, R.T. and J.C. Schultz. 1986. Food availability for forest birds: effect of prey distribution and abundance on bird foraging. Can. J. Zool. 66: $720-728$.

Howell, C.A., S.C. Latta, T.M. Donovan, P.A. Porneluzi, G.R. Parks and J. Faaborg. 2000. Landscape effects mediate breeding bird abundance in Midwestern forests. Landscape Ecol. 15: 547-562.

Lawler, J.J. and T.C. Edwards. 2002. Landscape patterns as habitat predictors: building and testing models for cavity-nesting birds in the Uinta Mountains of Utah, USA. Landscape Ecol. 17: 233-245.

Milsom, T.P., S.D. Langton, W.K. Parkin, S. Peel, J.D. Bishop, J.D. Hart and N.P. Moore. 2000. Habitat models of bird species' distribution: an aid to the management of coastal grazing marshes. J. Appl. Ecol. 37: 706-727.

Park, C. and W. Lee. 2000. Relationship between species composition and area in breeding birds of urban woods in Seoul, Korea. Landscape Urban Plan. 51: $29-36$.

SAS Institute Inc. 1985. SAS/STAT guide for personal computers, Version 8 edition. SAS Institute Inc. Cary. 378 p.

Saveraid, E.H., D.M. Debinski, K. Kindscer and M.E. Jakubauskas. 2001, A comparison of satellite data and landscape variables in predicting bird species occurrences in the Greater Yellowstone Ecosystem, USA. Landseape Ecol. 16: 71-83. 
Scott, J.M., F. Davis, B. Csuti, R. Noss, B. Buterfield, C. Groves, H. Anderson, S. Caicco, F. D'Erchia, T. Edwards, J. Ulliman and G. Wright. 1993. Gap analysis: A geographic approach to protection of biological diversity. J. Wildlife Manag. 57(1) supplement, Wildlife Monographs No. 123.

Seongnam City. 2001. Annual Statistics of Seongnam City.

U. S. Fish and Wildlife Service. 1981. Standards for the development of suitability index models. Ecological Services Manual 103. United States Department of Interior, Fish and Wildlife Service, Division of Ecological Services. Government Printing Office, Washington D.C., USA.

Van Horne, B. and J.A. Wiens. 1991. Forest bird habitat suitability models and the development of general habitat models. Fish Wildlife Research 8 . US
Fish and Wildlife Service

Verner, J., M.L. Morrison and C.J. Ralph. 1986. Wildlife 2000: modeling habitat relationships of terrestrial vertebrates. University of Wisconsin Press, Madison.

Vuilleumier, S. and R Prelaz-Droux. 2002. Map of ecological networks for landscape planning. Landscape Urban Plan. 58: 157-170.

Whelan, C.J. 2001. Foliage structure influences foraging of insectivorous forest birds: an experimental study. Ecology 82: 219-231.

Wiens, J.A. 1989. Spatial scaling in ecology. Funct. Ecol. 3: 385-397.

(Received November 30, 2004; Accepted February 15, 2005) 